\title{
The Structural Development of Folds Shapes in the Western Zagros Fold/Thrust Belt of Iraq Using Fourier Analysis
}

\author{
Nabeel K. Al-Azzawi \\ Department of Geology \\ College of Science \\ Mosul University
}

\author{
Nazar M. S. Numan \\ American University \\ Duhok Provost
}

(Received 18/7/2019 , Accepted 28/11/2019)

\begin{abstract}
Depending upon the geometrical shapes of the fold profiles, the Western Zagros Fold/ Thrust Belt of Iraq has been subdivided into different geometrically distinctive and genetically significant four sectors using Fourier ratios suggested by Hudleston classification. Furthermore, the same belt has been subdivided into eight sectors using Singh and Gairola's classification. The sector names of the former are chevronicsinusoidal, sinusoidal-parabolic, parabolic-semi elliptical and semi elliptical-box fold styles. Whereas in the later division, the sectors are almost chevronic, chevronicsinusoidal, almost sinusoidal, sinusoidal-parabolic, almost parabolic, parabolic-semi elliptical, almost semi elliptical and semi elliptical-box fold styles.

The investigation involves harmonic analysis (Fourier analysis) of the fold profiles by solving Fourier equations using the Gauss elimination method, determination of Fourier coefficients and Fourier ratios for forty major anticline structures that cover fairly evenly the Western Zagros Fold/ Thrust region. The procedure of harmonic analysis is carried out with FOLDN, a GWBASIC program written for this purpose. Fourier ratios are utilized for distinguishing different types of fold shapes.

In general, the map of these sectors shows that the folds become progressively more developed in shape towards the north and northeast. The arrangement of the obtained fold sectors in the studied area, matches the folds initiated first near the Alpine Suture and with time, they propagated south and southwestward across the axis of orogeny. In addition, probably the process is still going on.
\end{abstract}

Keywords: Fold shape, Fold development, Fourier analysis, WZFTB folds, Iraq

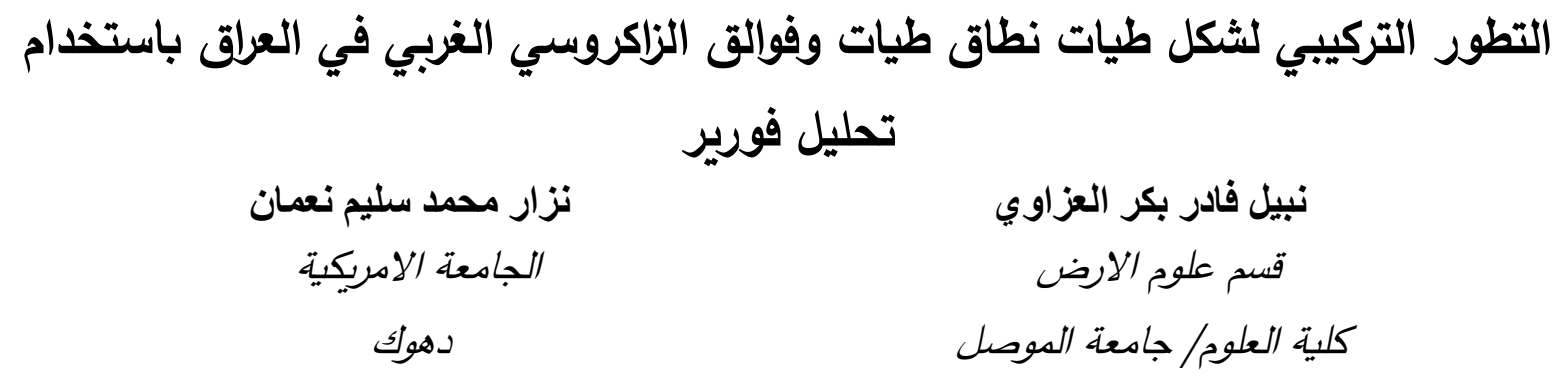




\begin{abstract}
المستخلص
اعتمادا على الثكل الهندي للطيات، قسم نطاق الطيات / الفوالق الزاكروسي الى أربعة قواطع تختلف هندسياً ومنشأياً عن بعضها وذلك باستخدام نسبة فورير حسب تصنيف هدلستون، والى ثمانية قواطع حسب تصنيف سيخ وكايرولا. وقد سميت هذه القواطع حسب طراز الطية من الاحدث هي شيفرونية-جيبية، جيبية-قطع مكافئ، قطع مكافئ-شبه اهليجي وأهليجي -صندوقي. وسميت حسب التصنيف الاخر تقربباً شفرونية، شفرونيةجيبية، تقربباً جيبية، جيبية-قطع مكافئ، تقريبا قطع مكافئ، قطع مكافئشبيه اهليجية، تقريبا شبه اهليجية وشبه إهليجية-صندوقية.

اتبع الاستقصاء التحليل الهارموني (تحليل فورير) لتحليل شكل الطية بحل معادلات فورير باستخدام طريقة الحذف لكاوس. وايجاد معاملات فورير ونسبة فورير لأربعين طية كبيرة توزعت في نطاق الطيات/ الفوالق الزاكروسي. وقد تم التحليل الهارموني باستخدام برنامج FOLDN وهو برنامج بلغة بيسك كتب لهذا الغرض. وحسبت نسبة فورير لتصنيف هذه الطيات حسب شكلها. عموما، أظهرت خارطة توزيع هذه القطاعات ان شكل الطيات يتطور تقادمياً نحو الثمال والثمال الثرقي. ان ترتيب هذه القواطع توضح انها بدأت من خط الدرز الألبي وتقدمت مع الزمن نحو الجنوب والجنوب الغربي

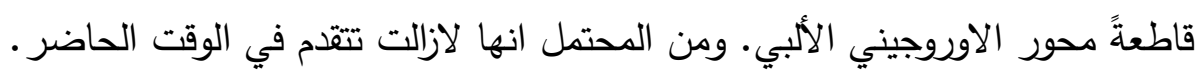
الكلمات الدالة: شكل الطية، تطور الطية، تحليل فورير ، الشمال الشرقي، العراق.
\end{abstract}

\title{
INTRODUCTION
}

The Western Zagros Fold/ Thrust Belt (WZFTB) contains simple faulted and folded strata, which is located between the latitudes $34^{\circ}-37^{\circ}$ north; and the longitudes $41^{\circ}-46^{\circ}$ east. The WZFTB Belt comprises two subdivisions namely High Folded and Low Folded zones. The former is located in the northeastern part whereas the latter is situated southwesterly. The thrust zone and the quasiplatform area bound the WZFTB from the north to the northeast and the south to the southwest respectively (Fig.1). Many descriptive studies were dealt with the WZFTB, which is previously called Folded Zone or Foreland Folds. These studies are Henson (1951), Dunington (1958), Bolton (1958), Ditmar et. al. (1971), Buday (1973), Ameen (1979), Numan (1984), Buday and Jassim (1987), Numan (1991), Numan and Al-Azzawi (1993), Numan (1997), Maroof (1999), Numan (2000) and Al-Azzawi (2003). In the present study, a mathematical technique is used for analyzing fold shape. This technique was called Fourier (harmonic) analysis, which depends on the principle of Fourier series. Fourier analysis is essentially used to determine the shapes of fold profiles and these were employed in this work to conclude the tectonic framework of the WZFTB.

Different authors like (Norris, 1963; Harbaugh and Preston, 1965; Whitten, 1966; Chapple, 1968) in Tripathi and Gairola (1999) had mentioned the Fourier analysis. In addition, it was modified by (Stabler, 1968), (Hudleston, 1973a), (Ramsay and Huber, 1987), (Bastida et al., 1999) and (Tripathi and Gairola, 1999). Three workers carried out field applications of this theory, Stowe (1988) in Zimbabwe used this technique in 
drawing fold profiles of sections taken from the Greenstone Belt. Singh and Gairola (1992) studied the area of North Almora Thrust. However, this study is restricted only to show the difference between the fold profiles of the para-autochthonous and allochthonous rocks. Moreover, Strivastava and Gairola (1997) in central India made the third study. They studied the Index of Nonharmony (INH) by Fourier analysis and they classified the folds in the area according to the Index of Nonharmony.

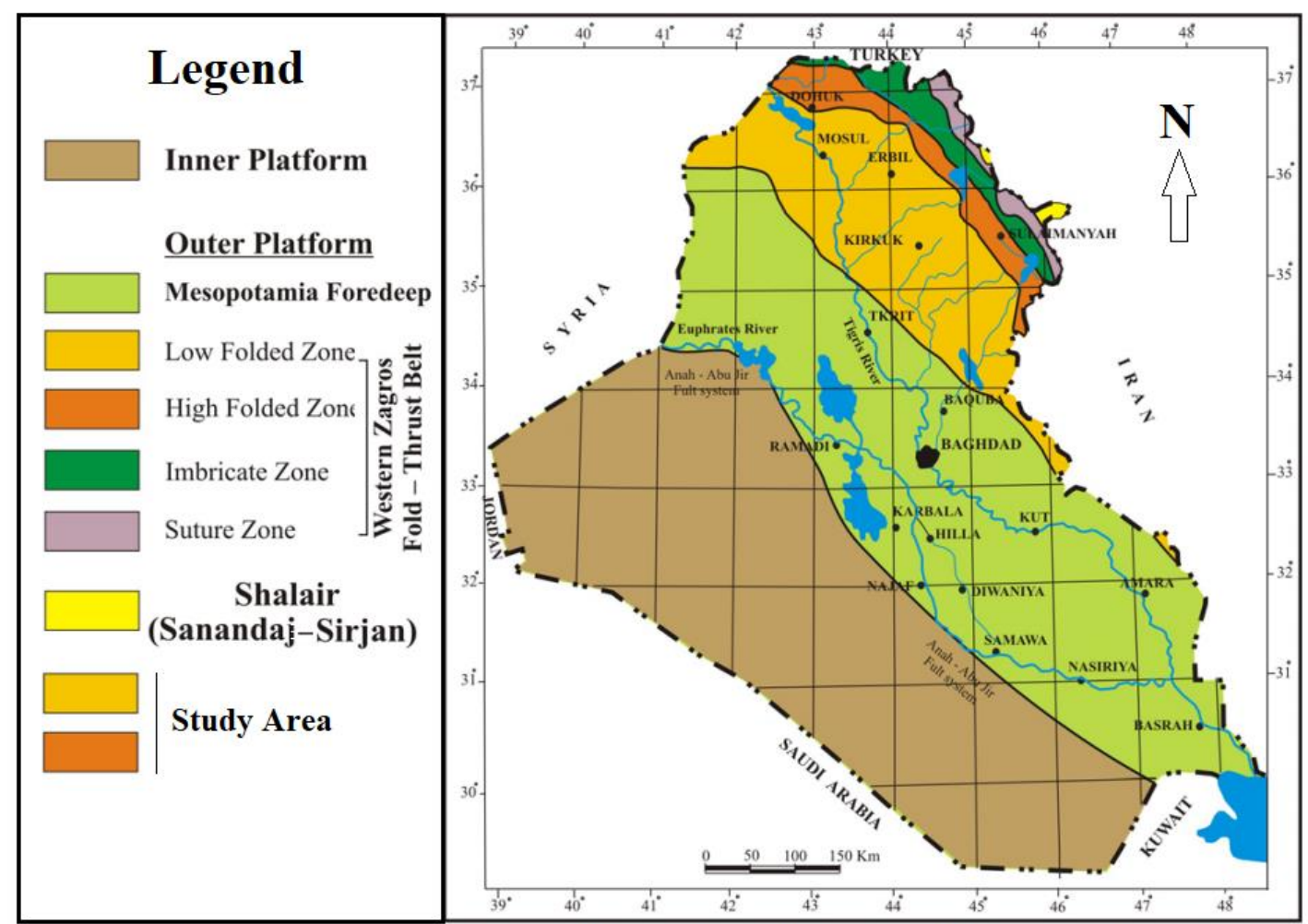

Fig.(1) The tectonic division of Iraq after (Fouad, 2012) and Location of the study area.

\section{METHODOLOGY}

\section{A: Theoretical point of view:}

The mathematical technique that involved in the present study is known as Harmonic or Fourier analysis. It uses a series of trigonometric functions to express the shape of folded strata.

$$
\begin{aligned}
F(X)= & a_{0}+a_{1} \operatorname{COS} X+a_{2} \operatorname{COS} 2 X+a_{3} \operatorname{COS} 3 X \\
& +b_{1} \operatorname{SIN} X+b_{2} \operatorname{SIN} 2 X+b_{3} \operatorname{SIN} 3 X
\end{aligned}
$$

By these functions, the curve of any folded layer can be defined and some coefficients called Fourier coefficients can be calculated as well. These coefficients are referred to the amplitude of various cosine and sine components. If a small part 
(sector) of the complete curve of sine function is selected, then the shape of this sector

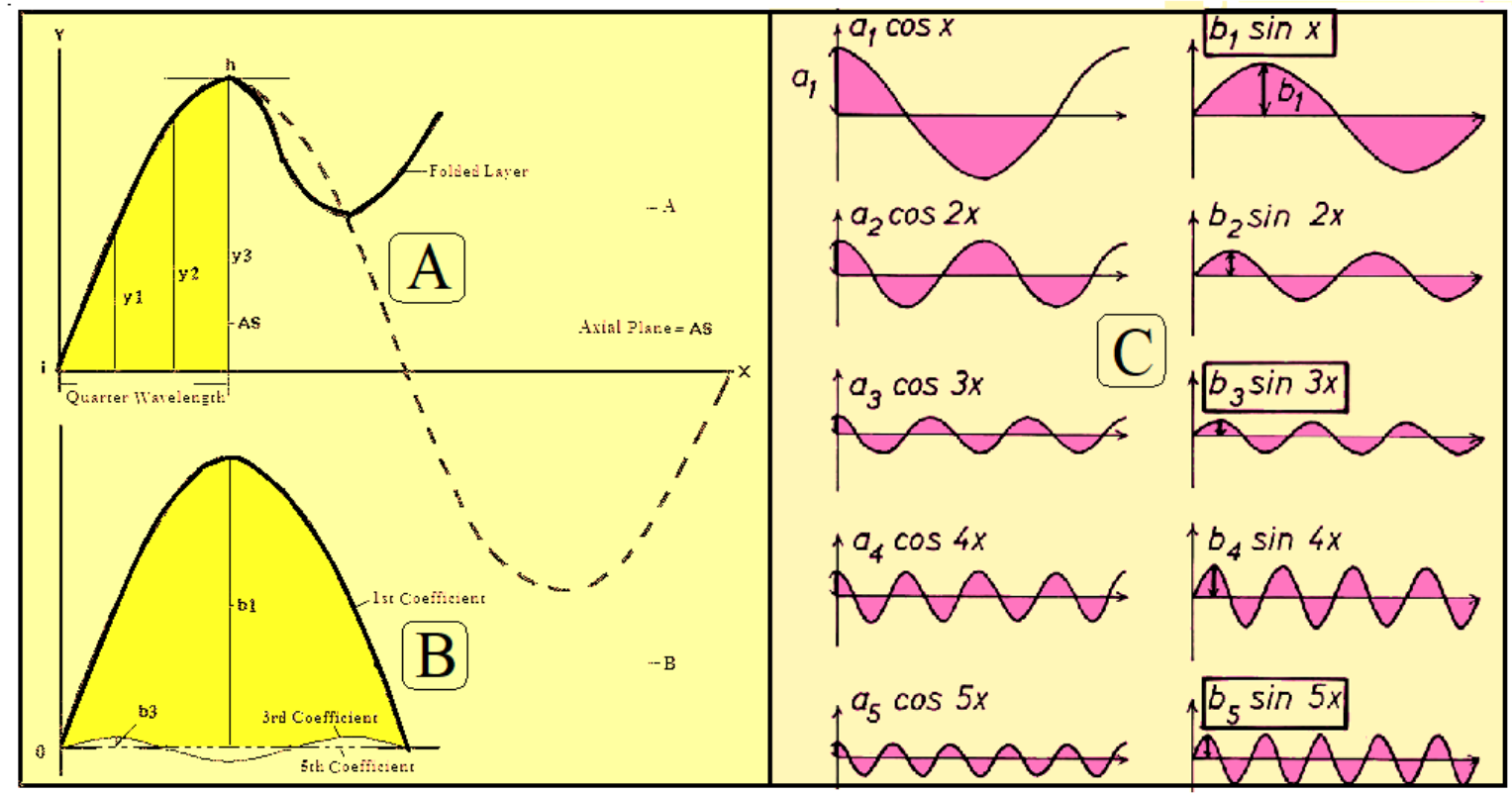

Fig. (2) A/ Determination of y1,y2 and y3 for quarterwavelength. B/ Location of Fourier Coefficients within the folded layer. $\mathrm{C} /$ Curves and Functions of Sine and Cosines.

can be defined by very few coefficients (Fig.2).

Therefore, the following Fourier equations are responsible for determining the coefficients $(b 1, b 3 \& b 5)$ :

$$
\begin{array}{|ccc}
\hline & Y_{1}=b_{1} \operatorname{SIN} X_{1}+b_{3} \operatorname{SIN} 3 X_{1}+b_{5} \operatorname{SIN} 5 X_{1} \\
& Y_{2}=b_{1} \operatorname{SIN} X_{2}+b_{3} \operatorname{SIN} 3 X_{2}+b_{5} \operatorname{SIN} 5 X_{2} \\
\ldots \ldots \ldots \ldots . & Y_{3}=b_{1} \operatorname{SIN} X_{3}+b_{3} \operatorname{SIN} 3 X_{3}+b_{5}
\end{array}
$$

For this purpose, three simple equations were derived by Stabler (1968) with approximate results of the Fourier coefficients. They are:

$$
\begin{gathered}
b_{1}=1 / 3\left(y_{3}+y_{1}\right)+\left[y_{2} /(2 \sin 60)\right] \\
b_{3}=1 / 3\left(2 y_{1}-y_{3}\right) \quad[1 /(2 \sin 60)=0.576] \\
b_{5}=1 / 3\left(\left(y_{3}+y_{1}\right)-y_{2} /(2 \sin 60)\right)
\end{gathered}
$$

The amplitude of any fold is derived from $b 1$; however, this can be slightly modified by $b 3$. Positive $b 3$ broadens the hinge area of any fold and produces a box fold whereas negative $b 3$ tends to steepen and straighten the limbs and produces a chevron fold. While the value of $b 5$ is so small and may be negligible.

The present authors suggested a mathematical procedure with a computer program to solve the Fourier Equation by Gauss Elimination Method (The computer program can be demand from the first author). 
Consequently, Fourier coefficients can be plotted graphically on the Hudleston diagram (Hudleston, 1973a) to find the shapes of the studied folds. The Hudleston's fold shapes are chevron, sinusoidal, parabolic, semi elliptical and box shape (Fig.3).

Experimentally, Ramsay and Huber (1987) studied the progressive changes of a fold shape during its growth versus the progressive deformation. They concluded that in the beginning of any deformation, the fold shape starts as chevron style then it is progressively changed into sinusoidal, parabolic, semi elliptical and box shape. The outcome of the two mentioned concepts means that (in the field) the box shape fold is older than others and the chevron fold is relatively the youngest.

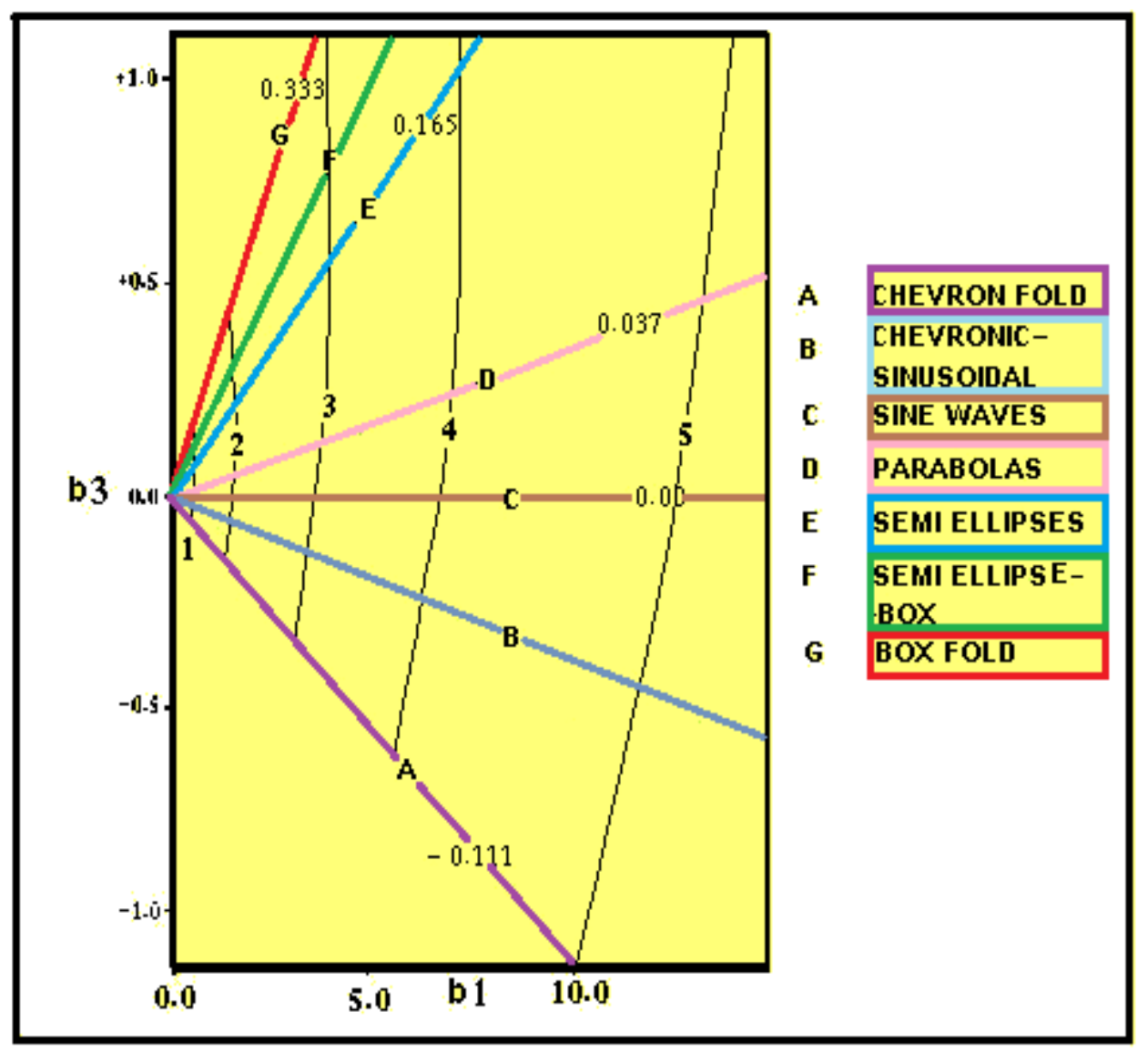

Fig. (3) Fold shapes after (Hudleston, 1973a)

Accordingly, the present study tried to apply the fold shapes, which were found by Fourier coefficients, on the progressive fold shapes of Hudleston' (1973a) and Ramsay and Huber (1987). This application was carried out in the WZFTB folds for the purpose of finding the relative ages of these folds and classifying them according to their relative ages.

\section{B- Application:}

For the sake of simplifying the application of this technique, two assumptions are adopted. First, the exposure points of the half wavelength of a fold are considered as inflection points. The validity of this consideration was empirically checked (Fig. 4). Second, is to take the measurements from the competent strata of parallel fold type of Ramsay (1967). In a parallel fold, the beds maintain constant thickness and the axial plane always bisects the interlimb angle, so it is easy to locate the trace of its axial 
plane. Naturally, there are no perfect parallel folds (Hudleston, 1973b; Ramsay and Huber, 1987) but there are combinations of more than one class of Ramsay's classification of multilayer folds (Ramsay, 1967). To apply this technique in northern Iraq, certain competent formations must be identified to take the measurements from. The most well known competent beds in the WZFTB are the Pila Spi Limestone Formation in the area eastern of Tigris River and Jeribe/Euphrates Formation in the western part. These formations are bounded by incompetent formations. Figure (5) shows that the competent layers must fold by parallel type (1B) whereas incompetent layers can take classes 1A, 1C and class 3 (Ramsay and Huber, 1987).

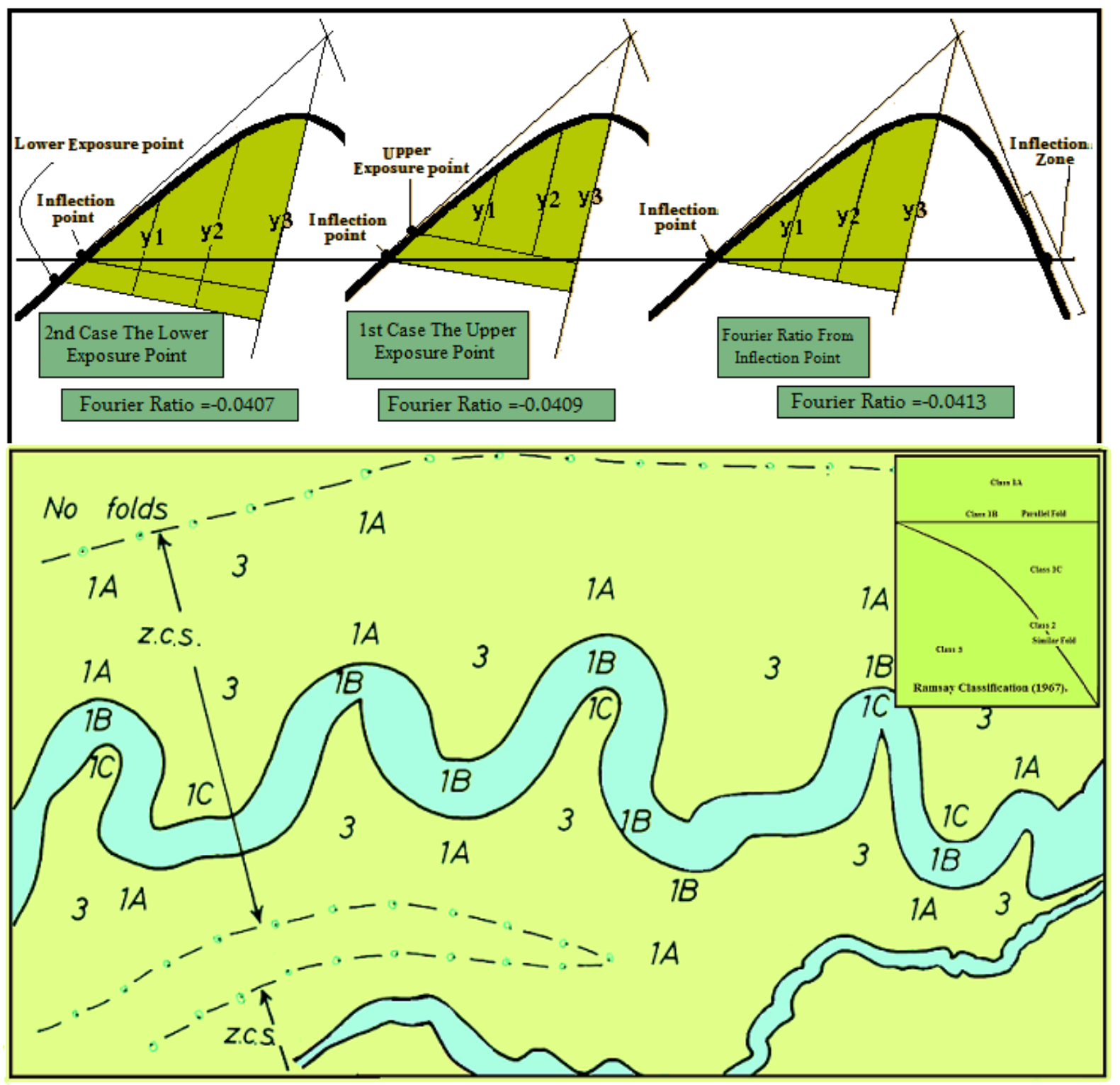

Fig. (5) Folding style of competent and incompetent layer, Ramsay and Huber (1987)

The procedure proposed and applied for this study contains the following items:

\section{1- Fold Profile Construction:}

Profile of the studied fold must be drawn for the preparation of Fourier analysis. Al-Azzawi (2004) proposed a mathematical method for the construction of fold profile 
with a computer program. The constructed fold profile must be framed with coordinating axes. The y-axis is parallel to the axial plane trace and passing through the inflection point, whereas the $\mathrm{x}$-axis must pass through the inflection point and perpendicular to axial plane trace (Fig.6).

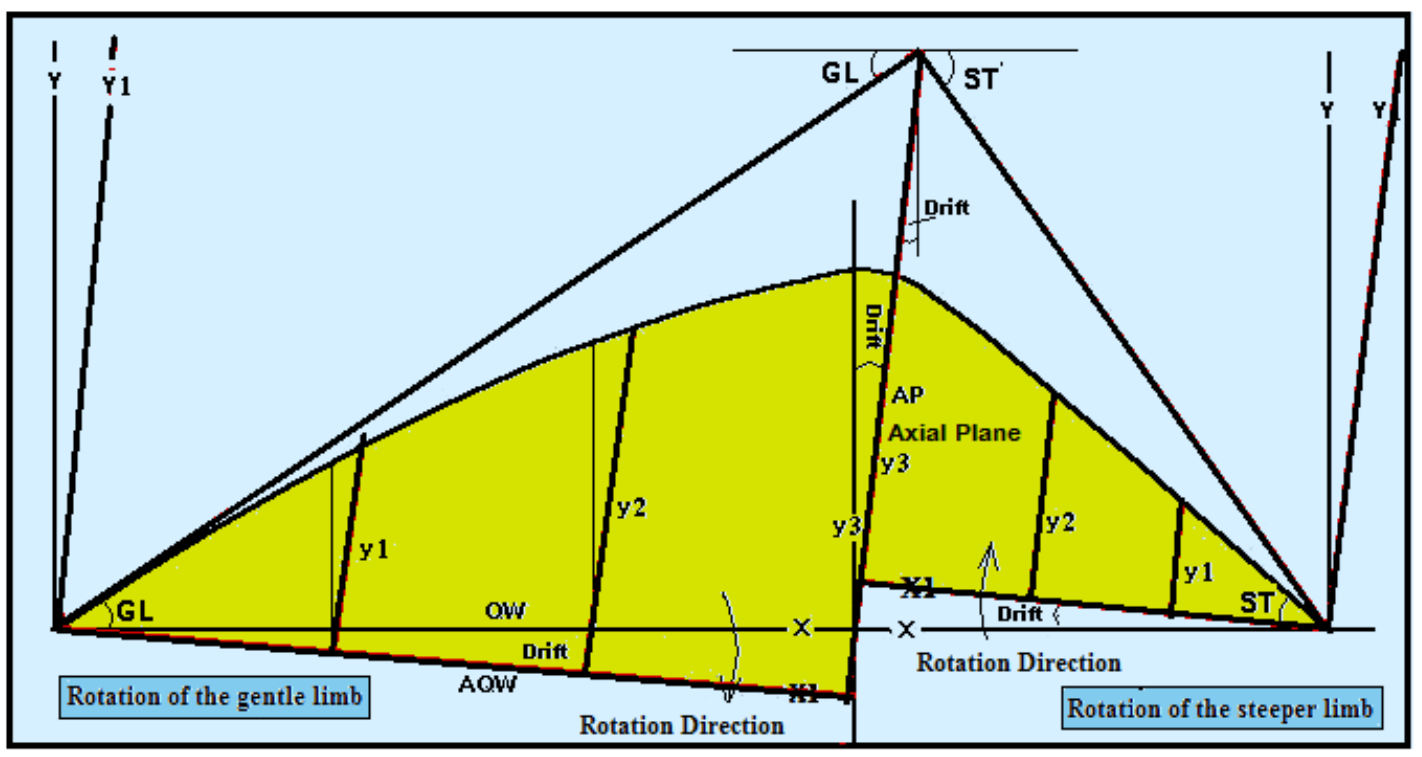

Fig. (6) Rotation of fold profile by drift angle and determination of Stabler axes of inclined axial plane.

\section{2-Rotation of Fold Profile:}

When the fold is symmetrical, the trace of its axial plane will be vertical, therefore $\mathrm{y}$-axis and $\mathrm{x}$-axis become vertical and horizontal respectively (i.e. the profile remains without rotation). While if the fold is asymmetrical, then rotation must be needed until, $\mathrm{y}$-axis and $\mathrm{x}$-axis become vertical and horizontal respectively. The angle of rotation Drift can be measured by the following equation:

Drift $=90-(((180-G L-S T) / 2)+G L)$

Where $G L$ is the dip angle of the gentle limb and $S T$ is for the steep one.

The deformational matrix method is used to rotate this profile (Fig.6), and the matrix listed below is needed to rotate the profile in clockwise direction:

Transformational Matrix $=$

$$
\left|\begin{array}{rr}
\operatorname{Cos}(\text { Drift }) & \text { Sin (Drift) } \\
-\operatorname{Sin}(\text { Drift }) & \text { Cos (Drift) }
\end{array}\right|
$$

The new $X$ and $Y$ values of the folded curve after rotation become:

$$
\begin{aligned}
& \mathrm{x}_{1}{ }^{-}=\mathrm{x}_{1} * \operatorname{Cos}(\text { Drift })+\mathrm{y}_{1} *-\operatorname{Sin}(\text { Drift }) \\
& \mathrm{y}_{1}{ }^{-}=\mathrm{x}_{1} * \operatorname{Sin}(\text { Drift })+\mathrm{y}_{1} * \operatorname{Cos}(\text { Drift })
\end{aligned}
$$

When the profile is needed to rotate in anticlockwise direction, the transformational matrix becomes:

Transformational Matrix =

$\left|\begin{array}{lr}\operatorname{Cos}(\text { Drift }) & -\operatorname{Sin}(\text { Drift }) \\ \operatorname{Sin}(\text { Drift }) & \operatorname{Cos}(\text { Drift })\end{array}\right|$


And the new $X$ and $Y$ values of the folded curve after rotation become:

$$
\begin{aligned}
& \mathrm{x}_{1}{ }^{-}=\mathrm{x}_{1} * \operatorname{Cos}(\text { Drift })+\mathrm{y}_{1} * \operatorname{Sin}(\text { Drift }) \\
& \mathrm{y}_{1}{ }^{-}=\mathrm{x}_{1} *-\operatorname{Sin}(\text { Drift })+\mathrm{y}_{1} * \operatorname{Cos}(\text { Drift })
\end{aligned}
$$

After rotating the fold profile, values of $X$ and $Y$ become:

$$
\left(\mathrm{x}_{1}^{-}, \mathrm{y}_{1}^{-}\right),\left(\mathrm{x}_{2}^{-}, \mathrm{y}_{2}^{-}\right), \ldots \ldots \ldots \ldots \ldots,\left(\mathrm{x}_{\mathrm{n}}^{-}, \mathrm{y}_{\mathrm{n}}^{-}\right)
$$

\section{3- Determination of a fold profile function:}

Many mathematical methods were experimentally used to calculate the fold function that can be used in the determination of Fourier coefficients. These methods are Lagrangian polynomial interpolation, the divided differences by Newton formula, Newton method for solution of nonlinear equations and Least Squares method. Empirically, it is proved that the Lagrangian polynomial interpolation is the best method for the presentation of the fold function and for interpolating points within the fold profile curve (eroded or missing points in the central part of the fold). Whereas the Least Squares method was used for extrapolation of the missing points on the fold profile terminations.

Application of Lagrangian Polynomial Interpolation:

The values of $X$ and $Y$ after rotating the fold profile are:

If $\mathrm{x}=\mathrm{x}^{-}$and $\mathrm{F}(\mathrm{x})=\mathrm{y}^{-}$, then they become

$$
\left(\mathrm{x}_{1}{ }^{-}, \mathrm{y}_{1}{ }^{-}\right),\left(\mathrm{x}_{2}^{-}, \mathrm{y}_{2}^{-}\right), \ldots \ldots \ldots \ldots \ldots . .,\left(\mathrm{x}_{\mathrm{n}}{ }^{-}, \mathrm{y}_{\mathrm{n}}{ }^{-}\right)
$$

$\begin{array}{cccccc}\mathrm{x}: & \mathrm{x}_{0} & \mathrm{x}_{1} & \mathrm{x}_{2} & \ldots \ldots \ldots \ldots \ldots & \mathrm{x}_{\mathrm{n}-1}\end{array}$

$\mathrm{F}(\mathrm{x}): \quad \mathrm{F}\left(\mathrm{x}_{0}\right) \quad \mathrm{F}\left(\mathrm{x}_{1}\right) \quad \mathrm{F}\left(\mathrm{x}_{2}\right) \quad \ldots \ldots \ldots \ldots, \mathrm{F}\left(\mathrm{x}_{\mathrm{n}-1}\right)$

The Lagrangian polynomial for degree of $\underline{n}$ is defined as the following:

$\mathrm{P}_{\mathrm{n}}(\mathrm{x})=\mathrm{F}\left(\mathrm{x}_{0}\right) \mathrm{L}_{0}(\mathrm{x})+\mathrm{F}\left(\mathrm{x}_{1}\right) \mathrm{L}_{1}(\mathrm{x})+\mathrm{F}\left(\mathrm{x}_{2}\right) \mathrm{L}_{2}(\mathrm{x})+\cdots-+\mathrm{F}\left(\mathrm{x}_{\mathrm{n}-1}\right) \mathrm{L}_{\mathrm{n}-1}(\mathrm{x})$

$$
\text { OR } \quad \mathrm{P}_{\mathrm{n}}(\mathrm{x})=\sum_{\mathrm{i}=0} \mathrm{~F}(\mathrm{xi}) \operatorname{Li}(\mathrm{x})
$$

And $\mathrm{Li}(\mathrm{x})$ for any value of $\mathrm{x}$ can be determined as:

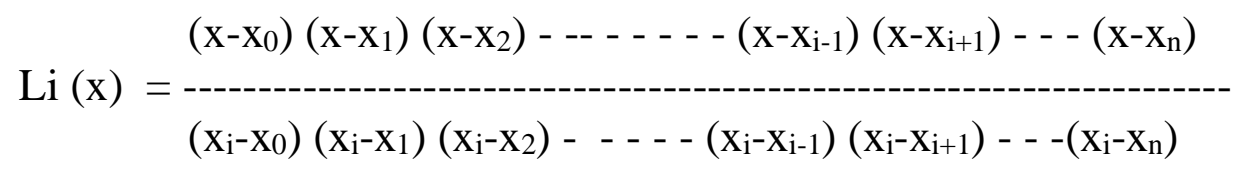

Application of Least Squares Method:

Determining the values of:

$\begin{array}{lllllll}\Sigma \mathrm{Xi} & \Sigma \mathrm{Xi}^{2} & \Sigma \mathrm{Xi}^{3} & \Sigma \mathrm{Xi}^{4} & \Sigma \mathrm{Yi} & \Sigma \mathrm{Xi} \mathrm{Yi} & \Sigma \mathrm{Xi}^{2} \mathrm{Yi}\end{array}$

Making the equations of Least Squares:

$\mathrm{a}_{0} \mathrm{~N}+\mathrm{a}_{1} \Sigma \mathrm{Xi}+\mathrm{a}_{2} \Sigma \mathrm{Xi}^{2}=\Sigma \mathrm{Yi}$

$\mathrm{a}_{0} \Sigma \mathrm{Xi}+\mathrm{a}_{1} \Sigma \mathrm{Xi}^{2}+\mathrm{a}_{2} \Sigma \mathrm{Xi}^{3}=\Sigma \mathrm{Xi} \mathrm{Yi}$

$\mathrm{a}_{0} \Sigma \mathrm{Xi}^{2}+\mathrm{a}_{1} \Sigma \mathrm{Xi}^{3}+\mathrm{a}_{2} \Sigma \mathrm{Xi}^{4}=\Sigma \mathrm{Xi}^{2} \mathrm{Yi}$

Arranging in matrix form: 


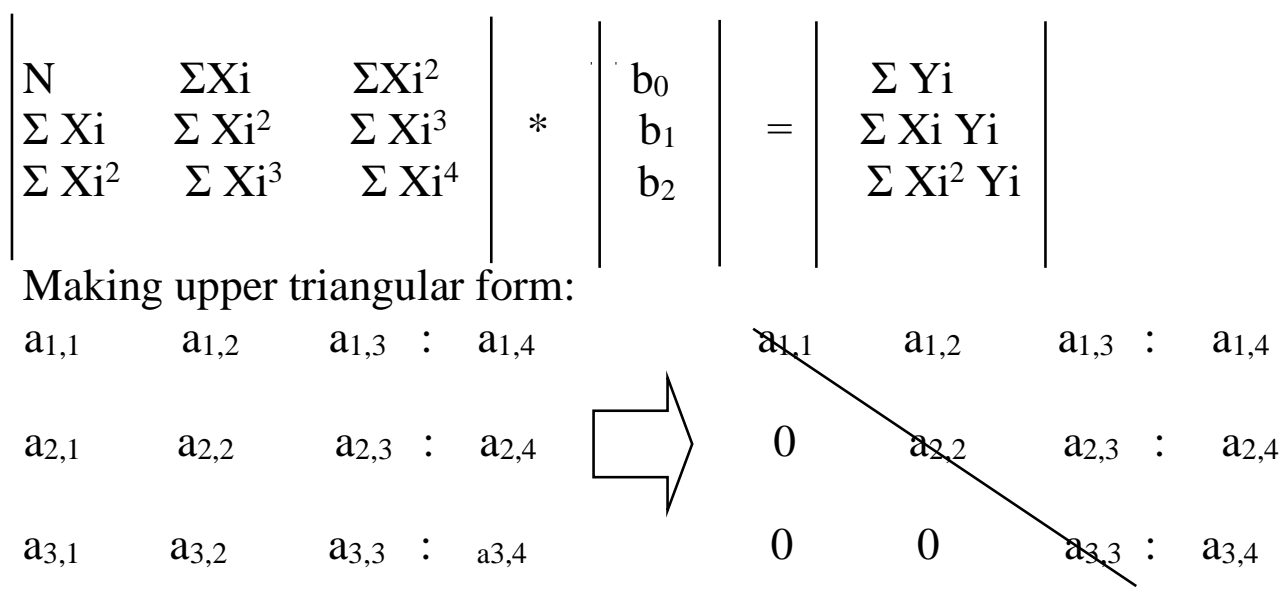

Calculating the values of the coefficients $\mathrm{a}_{1}, \mathrm{a}_{2}$ and $\mathrm{a}_{3}$ by back substitution method: $\mathrm{a}_{3,3} * \mathrm{~b}_{2}=\mathrm{a}_{3,4}$

$\mathrm{b}_{2}=\mathrm{a}_{3,4} / \mathrm{a}_{3,3}$

$a_{2,2} * b_{1}+a_{2,3} * b_{2}=a_{2,4}$

$\mathrm{b}_{1}=\left(\mathrm{a}_{2,4}-\mathrm{a}_{2,3} * \mathrm{~b}_{2}\right) / \mathrm{a}_{2,2}$

$a_{1,1} * b_{0}+a_{1,2} * b_{1}+a_{1,3} * b_{2}=a_{1,4}$

$\mathrm{b}_{0}=\left(\mathrm{a}_{1,4}-\mathrm{a}_{1,2} * \mathrm{~b}_{1}-\mathrm{a}_{1,3} * \mathrm{~b}_{2}\right) / \mathrm{a}_{1,1}$

Finally determining the form of fold function:

$$
\mathrm{Y}=\mathrm{a}_{0}+\mathrm{a}_{1} \mathrm{X}+\mathrm{a}_{2} \mathrm{X}^{2}
$$

\section{4- Determination of Stabler Axes:}

Stabler (1968) suggested simplified equations for determining the Fourier coefficients; in addition, he proposed a practical procedure for this purpose. He divided the base of a quarter wavelength after rotation (AQW) into three equal parts. For each part there is a value of $Y$, so there are three values $Y_{1}, Y_{2}$ and $Y_{3}$ called Stabler axes (Fig. 6). The corresponding $X$-values to $Y_{1}, Y_{2}$ and $Y_{3}$ are equal to 1/3 AQW, 2/3 AQW and AQW respectively. It must be known that $\mathrm{QW}$ is representing the quarter wavelength before rotation and the following formula is responsible for conversion:

$$
\mathrm{AQW}=\mathrm{QW} * \operatorname{Cos}(\text { Drift })
$$

Practically, Stabler axes can be measured directly from any fold profile (Fig. 6). The measurements must be converted to scaled values because different scales give different results. The scaled values of Stabler axes are convenient for the application of Fourier Equations. The following formula is used for the determination of the scaled values.

$$
\mathrm{Y}_{\mathrm{i}}=\mathrm{y}_{\mathrm{i}} * \Pi / 2 * \text { AQW } \quad \text { Stabler (1968) }
$$

\section{5- Arrangement of Fourier Equations:}

For the sake of the harmonic analysis of any natural fold, the three coefficients $b 1, b_{3} \& b_{5}$ can be taken into consideration and Fourier Equations can be arranged as follows: 


$$
\begin{aligned}
& Y_{1}=b_{1} \operatorname{SINX}_{1}+b_{3} \operatorname{SIN} 3 X_{1}+b_{5} \operatorname{SIN} 5 X_{1} \\
& Y_{2}=b_{1} \operatorname{SIN} X_{2}+b_{3} \operatorname{SIN} 3 X_{2}+b_{5} \operatorname{SIN} 5 X_{2} \\
& Y_{3}=b_{1} \operatorname{SIN} X_{3}+b_{3} \operatorname{SIN} 3 X_{3}+b_{5} \operatorname{SIN} 5 X_{3}
\end{aligned}
$$

To calculate the amounts of $b_{1}, b_{3} \& b_{5}$, the values of $X(1 / 3 \mathrm{AQW}, 2 / 3 \mathrm{AQW}$ and AQW) and their related $Y^{\prime s}$ must be substituted in the previous equations.

\section{6- Solution of Fourier Equations by Gauss Method:}

The solution of these equations in the previous step is very complicated; the present authors used the Gauss Elimination method to solve Fourier Equations by a computer program called FOLDN. The Gauss Elimination method was described by (Gerald and Wheatly, 1984). The following steps are explaining the procedure of the Gauss Elimination method.

Rewriting the Fourier Equation in the following form:

$$
\begin{aligned}
& b_{1} a_{1,1}+b_{3} a_{1,2}+b_{5} a_{1,3}=a_{1,4} \\
& b_{1} a_{2,1}+b_{3} a_{2,2}+b_{5} a_{2,3}=a_{2,4} \\
& b_{1} a_{3,1}+b_{3} a_{3,2}+b_{5} a_{3,3}=a_{3,4}
\end{aligned}
$$

Converting these equations to matrix form:

$$
\left|\begin{array}{ccc}
a_{1,1} & a_{1,2} & a_{1,3} \\
a_{2,1} & a_{2,2} & a_{2,3} \\
a_{3,1} & a_{3,2} & a_{3,3}
\end{array}\right| *\left|\begin{array}{l}
b_{1} \\
b_{3} \\
b_{5}
\end{array}\right|=\left|\begin{array}{l}
a_{1,4} \\
a_{2,4} \\
a_{3,4}
\end{array}\right|
$$

Making Upper triangular matrix:

$$
\left|\begin{array}{ccc}
a_{1,1} & a_{1,2} & a_{1,3} \\
0 & a_{2,2} & a_{2,3} \\
0 & 0 & a_{3,3}
\end{array}\right| *\left|\begin{array}{l}
b_{1} \\
b_{3} \\
b_{5}
\end{array}\right|=\left|\begin{array}{l}
a_{1,4} \\
a_{2,4} \\
a_{3,4}
\end{array}\right|
$$

Calculating the values of $b 1, b 3 \& b 5$ coefficients by back substitution method:

$$
\begin{aligned}
& a_{3,3} b_{5}=a_{3,4} \\
& \mathrm{~b}_{5}=\mathrm{a}_{3,4} / \mathrm{a}_{3,3} \quad \ldots \ldots \ldots \ldots \ldots \ldots \ldots \ldots \ldots \ldots \ldots \\
& a_{2,2} b_{3}+a_{2,3} b_{5}=a_{2,4} \\
& b_{3}=\left(a_{2,4}-a_{2,3} b_{5}\right) / a_{2,2} \ldots \ldots \ldots \ldots \ldots \ldots .2 \\
& a_{1,1} b_{1}+a_{1,2} b_{3}+a_{1,3} b_{5}=a_{1,4} \\
& b_{1}=\left(a_{1,4}-a_{1,2} b_{3}-a_{1,3} b_{5}\right) / a_{1,1} \ldots \ldots \ldots . .3
\end{aligned}
$$

The ratio $b 3 / b 1$ is called Fourier Ratio, which is used for determining the fold shape. This is because $b 5$ is negligible in the macroscopic folds studies.

\section{7- Hudleston Classification:}


The Fourier ratio can be applied on Hudleston Diagram (Fig.3) to determine the shape style of the studied fold.

\section{8-Singh and Gairola Classification:}

The same ratio can also be applied for Singh and Gairola Diagram (Fig.7) to determine the precise shapes of the studied folds.

\section{PROGRESSIVE CHANGE OF FOLD SHAPES DURING EXPERIMENTAL FOLDING}

Folds are found in nature in their final stage of development. Therefore, Hudleston (1973b), Ramasy, and Huber (1987) experi-mentally tried to study the progressive growth of folds with physical models. They found out that folds could pass through different shapes when they progressively grow. Hudleston (1973b) carried out his experiment in a shear box using Ethyl cellulose substance for his model. He found that the strata were started folding by sinusoidal shape, became progressively developed to parabolic and semi elliptical shape with increasing stresses. Ramsay and Huber (1987) used Plasticine substance for their model. This laboratory experiment was passed through four stages; a certain fold shape represented each stage. The first stage was manifested by chevron-sinusoidal shape whereas the second and third stages had almost sinusoidal and parabolic shapes respectively. The fourth stage appeared as almost semi elliptical shape and the hinge zones became more rounded with increasing stresses until reaching box-like shape.

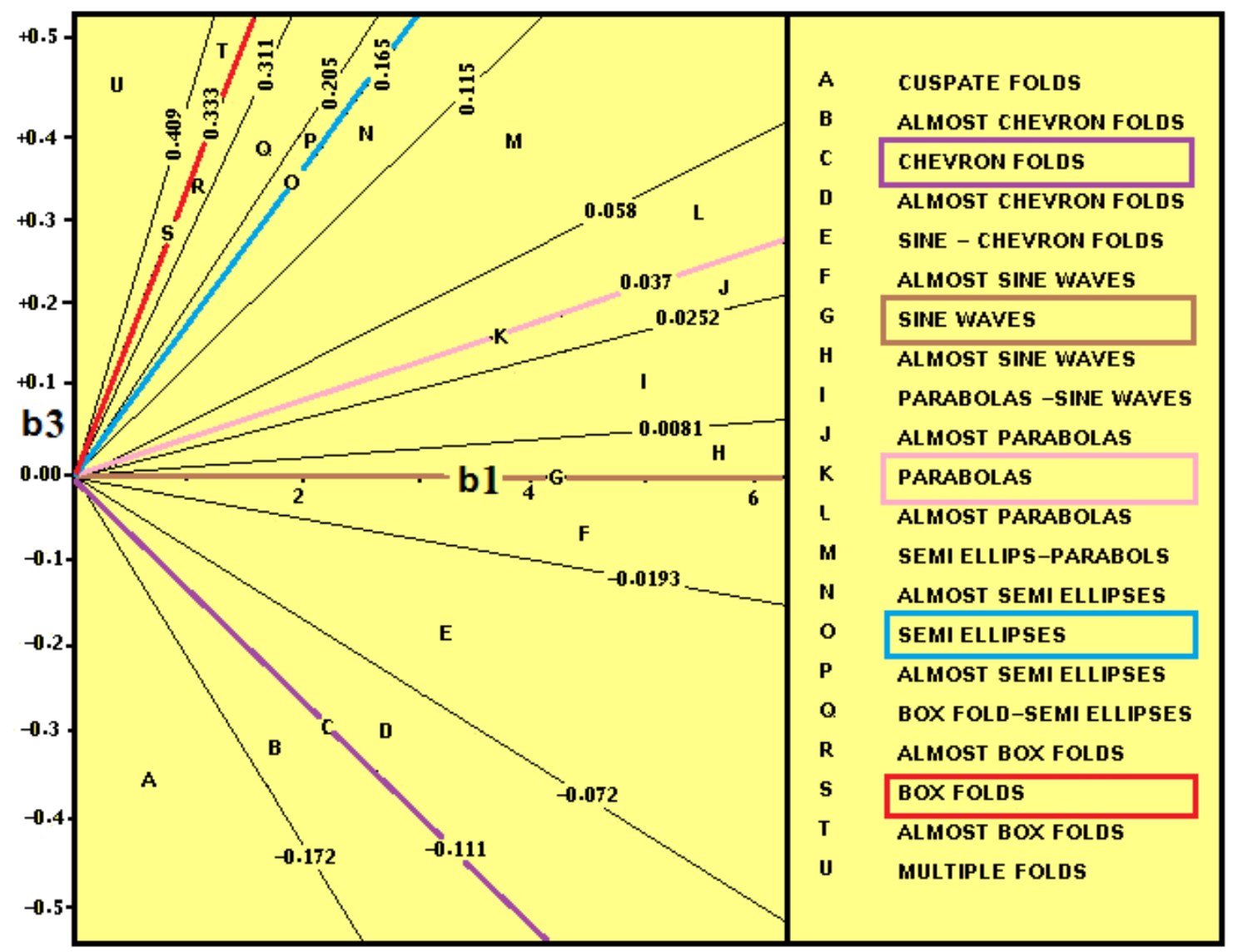

Fig. (7) Fold shapes after Singh and Gairola (1992) 
From the aforementioned experiments, it may be concluded that the shape of any fold can grow progressively from chevron, sinusoidal, parabolic, semi elliptical and box shape. Moreover, if this conclusion is considered as a geological truth and can be applied in the geological field, it means that the chevron fold is relatively younger than semi elliptical one, and the box type fold is the oldest.

\section{FOURIER OR HARMONIC ANALYSIS OF THE WZFTB FOLDS}

According to the previous aspects of defining fold shape by Fourier analysis and the chronological ascending of the fold shape styles, the present authors had subjected 40 folds of the WZFTB of Iraq to this application. Consequently, it is found that the WZFTB folds could be divided into four sectors according to the Hudleston division (Fig.8). These are:

\section{1- Chevronic-Sinusoidal Folds Sector:}

The folds in this sector have Fourier ratios ranging from -0.111 to 0.000 . These folds are Ain Zalah, Zeneat, Qand, Mandan, Ain Alsafra, Almeshraq, Butmah East, Butmah West, Ishkaft, Sinjar, Sasan, Zumbar, Shaikh Ibrahim and Adaiya. There are two folds in this sector in anomalous manner, they are Bahshiqa and Khorsubad with sinusoidal-parabolic and under chevronic shape respectively.

\section{2- Sinusoidal-Parabolic Folds Sector:}

This sector comprises folds ranging in their Fourier ratios from 0.000 to 0.037. These folds are Baikher, Shaikhan, Bana Bawi, Darband Bazian, Mashorah Dagh, Hemrin North, Hemrin South and Kirkuk. The anomalous folds in this sector are Duhok, Dahkan, Makhul and Qara Chauq that have parapolic-semi elliptical shape and Chamchamal, Permum Dagh and Zakho with chevronic-sinusoidal shape.

\section{3-Parabolic-Semi Elliptical Folds Sector:}

Fourier ratios of this sector are ranging from 0.037 to 0.165 . The sector comprises Charveki Dagh, Safine Dagh, Shakrok, Harir, Berat, Bazian South, Bazian North and Pera Magron.

\section{4-Semi Elliptical - Box Folds Sector:}

This sector is containing a single fold. It is Chia Gara Anticline, which has Fourier ratio equal to 0.2659 . This sector represents a higher degree of development in the WZFTB.

When the same folds are subjected to the Singh and Gairola divisions (Singh and Gairola, 1992) (Fig. 7), then the WZFTB folds can be divided into 8 precise sectors, due to small intervals of Fourier ratio (Fig.7).

These sectors are:

1- Almost Chevronic Folds.

3- Almost Sinusoidal Folds.

5- Almost Parabolic Folds.
2- Chevronic-Sinusoidal Folds.

4- Sinusoidal - Parabolic folds.

6- Parabolic-Semi Elliptical Folds. 
7- Almost Semi Elliptical Folds. 8-Semi Elliptical-Box Folds.

\section{DISCUSSION}

The application of Fourier analysis according to Hudleston and Ramsay and Huber experiments on the WZFTB folds reveals two important tectonic results. The first one is the homogeneous and progressive change of folds' shapes in the WZFTB. The second result is the anomalous folds in this Belt.

\section{Progressive folds' shapes:}

Figure (8) explains the homogenous and progressive change of folds' shapes in the WZFTB. It shows that the fold shapes of this belt are progressively advancing toward the north and the northeast. The fold shapes appeared as chevronic-sinusoidal folds (first sector) in the south and southwest of the WZFTB had been advanced toward the north and northeast to semi elliptical-box folds (fourth sector). This indicates that the ages of these folds are increasing to the north and northeast parts. Figure (8) shows the four sectors of folds' shapes according to (Hudleston, 1973a) and describes the tectonic development of the WZFTB folds as well. Thus according to the results of Hudleston (1973a) and Ramsay and Huber (1987) experiments, the semi elliptical- box folds sector is considered the older sector in the WZFTB, whereas the chevronic-sinusoidal folds sector is relatively younger.

Using the assumption of fold shape as an indicator for folds development, the analysis results reveals that Semi elliptical fold must be started as chevron fold, then it became sinusoidal and parabolic. Accordingly, the folds of the fourth sector (semi elliptical-box) in the WZFTB might be started with chevron or chevronic-sinusoidal folds at the beginning of Arabian Eurasian plates' collision. After that, when the folds of the third sector (parabolic-semi elliptical) started as chevron folds, the folds of the fourth sector were grown to sinusoidal-parabolic folds. Moreover, when the folds of the second sector (sinusoidal-parabolic) formed as chevron folds, the third sector was developed to sinusoidal-parabolic folds and the folds of the fourth sector became parabolic-semi elliptical folds and so on.

There are two evidences confirm the present interpretation. First, the boundaries of these sectors are parallel to the Bitlis - Zagros suture line, which is a result from the collision of the Arabian and Eurasian (Iranian and Turkish) plates. This means that these boundaries (at any point) are generally perpendicular to $\delta_{1}$ stress axis and parallel to $\delta_{3}$ stress axis of the regional stress trajectories. The second evidence is the geographic locations of these sectors are coinciding with their tectonic settings. This means that the fourth sector, which comprises the higher developing folds is located close to the suture line (the source of the tectonic force). 


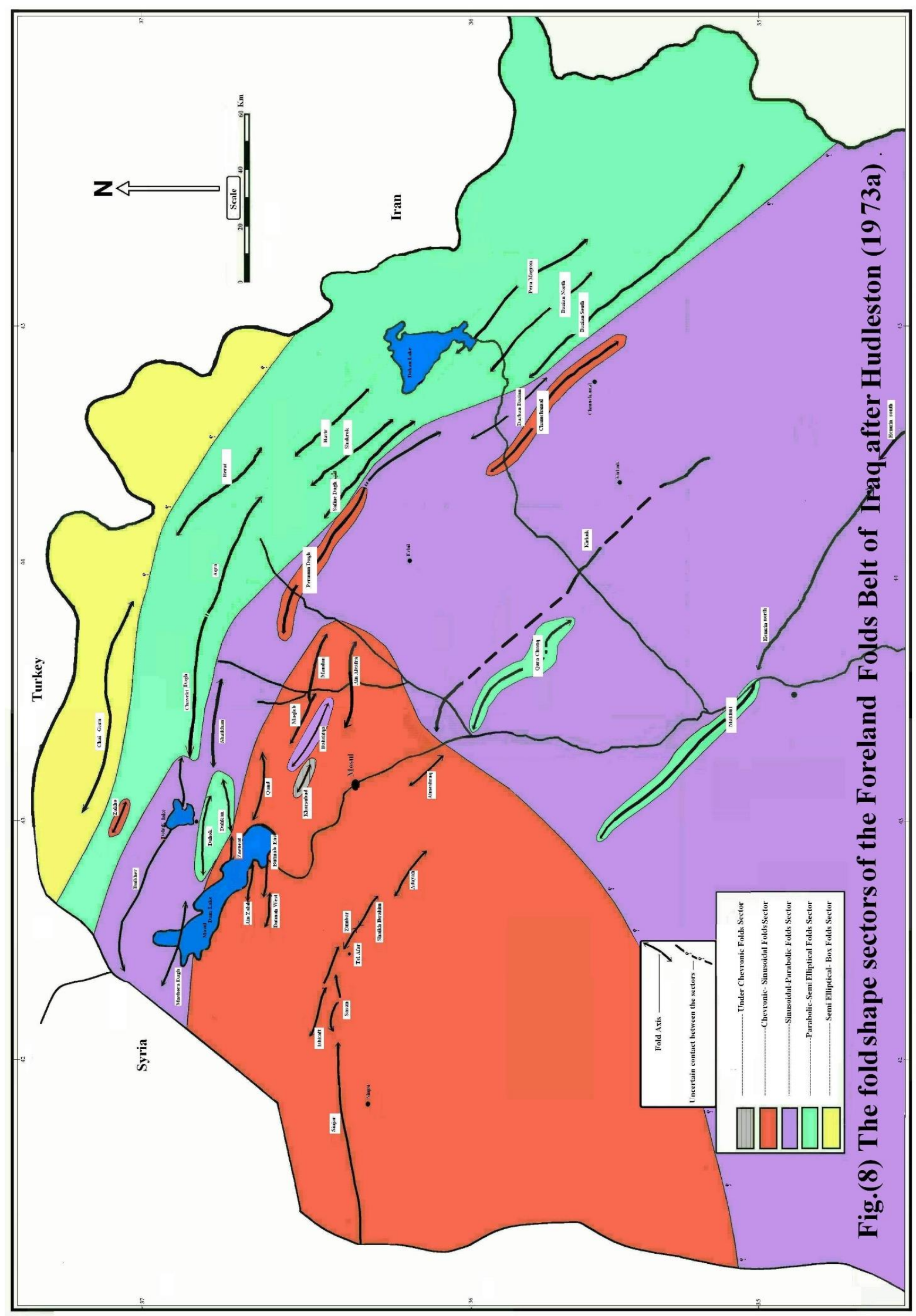




\section{The anomalous folds:}

During the course of this analysis, some folds appear as anomalous folds in their sectors. These are:

1- Bahshiqa (sinusoidal-parabolic) and Khorsubad (under chevronic) folds which appeared within the chevronic-sinusoidal folds sector.

2- Duhok, Dahkan, Makhul and Qara Chauq folds (parapolic-semi elliptical) and Chamchamal, Permum Dagh and Zakho folds (chevronic-sinusoidal) which are located within the sinusoidal- parabolic sector.

It is also conspicuous that Bahshiqa, Duhok, Dahkan, Makhul and Qara Chauq are anomalous folds having higher developed fold shapes than their sector shape. While the other anomalous folds; Korsubad, Chamchamal, Permum Dagh and Zakho have lower developed fold shapes than their sector shape. Numan and Al- Azzawi (1993) and Al-Azzawi (2003) suggested that there were basement faults called listric faults that had controlled the formation of the WZFTB folds. These faults were divided into two types according to the fault vergence. They are Foreland -vergent listric faults, which made folds vergent toward the south, or the southwest and suture-vergent listric faults that made folds vergent toward the north or the northeast. The present authors propose that when the listric fault had a higher displacement than the surrounding faults, the associated fold becomes anomalous in its sector like Bahshiqa, Duhok, Dahkan, Makhul and Qara Chauq. While if the listric fault had a lower displacement than the surroundings, then the related fold also becomes anomalous in its sector like Permum Dagh, Chemchamal and Zakho. The listric fault in the first case was called Progressive Fault. While it was named Retard Fault in the second case.

\section{REFERENCES}

Al-Azzawi N. K. B., 2003. The structural Determination of Folds Shape in The Foreland Folds Belt of Iraq, and Its Tectonic Implications, Unpublished $\mathrm{PhD}$ Thesis, University of Mosul.

Al-Azzawi, N.K.B., 2004. Determination of fold profiles and functions, a mathematical approach, Iraqi Jour. of Earth Science.

Ameen M. S., 1979. Regional Investigation of Geoflexures and Tectonic Analysis in the Simple Folded Zone of Iraq, Unpublished M.Sc. Thesis, Univ. of Mosul.

Bastida, F., Aller, J. and Bobillo-Ares, N.C., 1999. Geometric analysis of folded surfaces using simple functions, Journal of Structural Geology, 21, 729-742.

Bolton, C. M. G., 1958. The geology of Rania area, Site Invest. Co. Rep. Vol. IXB P. 117, D.G. Geol. Surv. Min. Inves. Lib. Rep. No. 271 Baghdad, Iraq.

Buday, T., 1973. Regional Geology of Iraq, Geoserv., Baghdad, Unpub.

Ditmar, V., Afanasiev, J., and Shanakova, E., 1971. Geological conditions and hydrocarbon respects of the Republic of Iraq (northern and central parts), INOC 
Library, Baghdad, Iraq.

Dunington, H. V., 1958. Generation, Migration, accumulation and dissipation of oil in northern Iraq. Habitat of oil a symposium. Amer. Assoc Petrol. Geol. Tulsa, G.L. Weeks (Editor) pp. 1194-1251.

Fouad, S.F.A., 2012a. Tectonic Map of Iraq scales 1: 1000 000, 3rd edit., GEOSURV, Baghdad, Iraq.

Gerald, C. F. and Wheatley, P.O., 1984. Applied Numerical Analysis, AddisonWesley Publishing Company, 3 th ed., 579p.

Henson, F. R. S., 1951. Oil occurrences in relation to regional geology of the Middle East, Tulsa Geol. Soc. Digest, Vol. 19, pp. 72-81.

Hudleston, P.J., 1973a. Fold morphology and some geometrical implications of theories of fold development, Tectonophysics, 16, 1-46.

Hudleston, P.J., 1973b. Analysis of single-layer folds developed experimentally in viscous media, Tectonophysics, 16, 189-214

Maroof, N. Z., 1999. Dynamic evolution of sedimentary basins in northern Iraq and hydrocarbon formation, migration and entrapment, Unpublished Ph.D. thesis, University of Baghdad, Iraq.

Numan, N. M. S.,1991. Extensional and Wrench Tectonics in the WZFTB Folds in Iraq with Geotectonic implications, First Inter. Conf. On the Geol. Of Arab World, Cairo.

Numan, N. M. S., 1997. A plate tectonic scenario for the Phanerozoic succession in Iraq, Geol. Soc. Iraq. Jour., Vol. 30, No. 2, pp. 85-110.

Numan, N. M. S., 2000. Major Cretaceous Tectonic Events in Iraq, Raf. Jour. Sci. Vol. No. 3, pp.32-52.

Numan, N. M. S., and Al-Azzawi, N. K. B., 1993. Structural and geotectonic interpretation of vergence directions of the anticlines in the WZFTB folds, Abhath Al-Yarmouk (pure science and engineering), Yarmok University, Jordan, Vol.2, No. 2, pp.57-73.

Ramsay, J. G., 1967. Folding and Fracturing of Rocks, McGraw Hill, New York, 568.

Ramsay, J. G., and Huber, M. I., 1987. The techniques of modern structural geology: V.2, Folds and Fractures, Academic Press, London, UK, 700p.

Singh, R.A., and Gairola, V.K., 1992. Fold Shape in the vicinity of North Almora Thrust in District Chamoli, Garhwal Himalaya, Journal of Himalayan Geology, Vol. 3, No.2, pp. 121-129.

Stabler, C.L., 1968. Simplified Fourier analysis of Fold Shape, Tectonophysics, Vol. 6, No. 4, pp. 343-350.

Strivastava, V., and Gairola, V.K., 1997. Classification of multilayered folds based on harmonic analysis: example from central India, Journal of Structural Geology, Vol. 19, No. 1, pp. 107-112.

Stowe, C. W., 1988. Application of Fourier analysis for computer representation of fold profiles, Tectonophysics, Vol. 156, pp. 303-311.

Tripathi, A. and Gairola, V.K., 1999. Fold symmetry- a quantitative description, Journal of Structural Geology, Vol. 21, pp.719-727. 